\title{
GEO-STATISTICAL ASSESSMENT OF GROUND WATER QUALITY IN DHAMAR BASIN, YEMEN
}

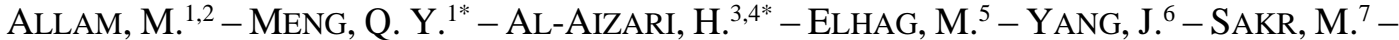 \\ WANG, Z. ${ }^{1}$ \\ ${ }^{1}$ Aerospace Information Reseach Institute, Chinese Academy of Sciences, Beijing 100094, China \\ ${ }^{2}$ Environment \& Climate Change Research Institute, National Water Research Center, Cairo, Egypt \\ ${ }^{3}$ Department of Chemistry, Faculty of Education, Thamar University, Yemen \\ ${ }^{4}$ Laboratory of Biotechnology, Environment and Quality - UFR of process engineering, Faculty \\ of Sciences, Ibn Tofail University, BP 133, Kenitra, 14000, Morocco \\ ${ }^{5}$ Department of Hydrology and Water Resources Management, Faculty of Meteorology, \\ Environment \& Arid Land Agriculture, King Abdulaziz University, Jeddah 21589, Saudi Arabia \\ ${ }^{6}$ Sanya Institute of Remote Sensing, Sanya 572029, China \\ ${ }^{7}$ GIS and RS at King Mariout high Institute, Cairo, Egypt \\ *Corresponding authors \\ e-mail:mengqy@radi.ac.cn (Meng,Q.Y.); Alaizari2@gmail.com (Al-Aizari, H.) \\ (Received 29 $9^{\text {th }}$ Apr 2019; accepted 31 ${ }^{\text {st }}$ Oct 2019)
}

\begin{abstract}
Groundwater quality in the Basin of Dhamar (Yemen) has been studied using geographic information system (GIS), principal component analysis (PCA) and correlation technique. A geographic information system is a tool for mapping and analyzing spatial data and is also used to retrieve groundwater quality information. For this study 26 wells were selected, for each well thirteen physicochemical parameters were analyzed including electrical conductivity, Calcium $\left(\mathrm{Ca}^{2+}\right)$, Magnesium $\left(\mathrm{Mg}^{2+}\right)$, Sodium $\left(\mathrm{Na}^{+}\right)$, potassium $\left(\mathrm{K}^{+}\right)$, bicarbonate $\left(\mathrm{HCO}_{3}^{-}\right)$, Chloride $\left(\mathrm{Cl}^{-}\right)$, Sulphate $\left(\mathrm{SO}_{4}{ }^{2-}\right)$, Nitrate $\left(\mathrm{NO}_{3}\right)$, Iron $\left(\mathrm{Fe}^{2+}\right)$, Fluoride $\left(\mathrm{F}^{-}\right)$and Total Hardness $(\mathrm{TH})$. The collected groundwater was evaluated for its suitability for both drinking and irrigation purposes. Correlation and PCA have been utilized to analyze the parameters. Cartographic maps of the study area have been generated using multivariate statistical tools and GIS approach Inverse Distance Weighting (IDW) for all the above parameters. The created maps can be used to visualize, analyze, and understand the relationship among all locations. Most of the wells are found to be within the permissible limit except one well and this is due to the anthropogenic pollution received by human activities. Correlation and principal component analysis can help in selecting the most significant parameters to determine the status of water quality. The tools available in the GIS environment supported the study in the integration of data with very different data structures, i..e. point, $2 \mathrm{D}$ and 3D, towards spatial modeling of processes relevant to the assessment of groundwater resources.
\end{abstract}

Keywords: ground water quality, $P C A, I D W$, piper diagram, Yemen

\section{Introduction}

Water is a source of life for life. This substance must be preserved from all influences: modern civilization, industrialization, urbanization, and an increase of the population (Kot et al., 2000; Rafiullah et al., 2012). The groundwater contamination in an urban environment is due to the infiltration of domestic untreated wastewater into the natural receiving environment, accentuated by favorable hydrogeological conditions (Ayad and Kahoul, 2016). Around the world, pressure on water resources and particularly on groundwater resources is on the rise, mainly due to increasing demand. 
The captured water may contain elements that may have adverse health effects, such as pathogenic microorganisms, unwanted substances or even toxic substances (Hartemann, 2000; Patil et al., 2012). Determining the quality of groundwater is important in deciding whether water is safe to drink, agriculture or industry. Water quality is a concept that refers to the chemical, biological and physical characteristics of water. The quality of the water required is determined by the purpose for which the water is to be used (domestic, urban, agricultural or industrial). Evaluation of water for uses is based on the characteristics of the water in relation to the quality required. In relation to drinking water, the required quality is defined by "standards" which define concentrations of constituents so that they have no adverse effect on the health of the consumer during the lifetime of consumption (Bakraji and Karajo, 1999).

Yemen is one of the countries most threatened by lack of water, it is already facing a serious water crisis: the annual consumption per individual is mediocre $\left(135 \mathrm{~m}^{3}\right)$ compared to that recorded in the Middle East and North Africa $\left(1250 \mathrm{~m}^{3}\right)$. Many cities face a serious water shortage, the prospect of sustainability of water resources, the main source of concern is the ever-increasing demand for water in water supply and irrigated groundwater agriculture in the same well field area (Glass, 2010; Whiting et al., 2011).

The aims of this study are to evaluate the groundwater quality of the Dhamar basin and its purposes for drinking and irrigation using GIS, correlation, and PCA, the second is to understand the variations in water quality in this reservoir.

\section{Materials and Method}

\section{Study area}

The governorate of Dhamar is situated in the middle of central highlands of Yemen with an area of $7.586 \mathrm{~km}^{2}$ and $2700 \mathrm{~m}$ above sea level, it is divided into 12 administrative districts and 314 sub-districts (Figure 1). Dhamar has located $100 \mathrm{~km}$ to the south of Sana'a and north of Ibb city and west of Al-Beidha. Dhamar city is the capital of the governorate and it is situated on the main road that connects Sana'a with several other governorates. Dhamar basin is one of the largest water basins in Yemeni governorates and the most depletion one with over 6000 wells lastly reported in 2009 (Al-Aizari et al., 2017).
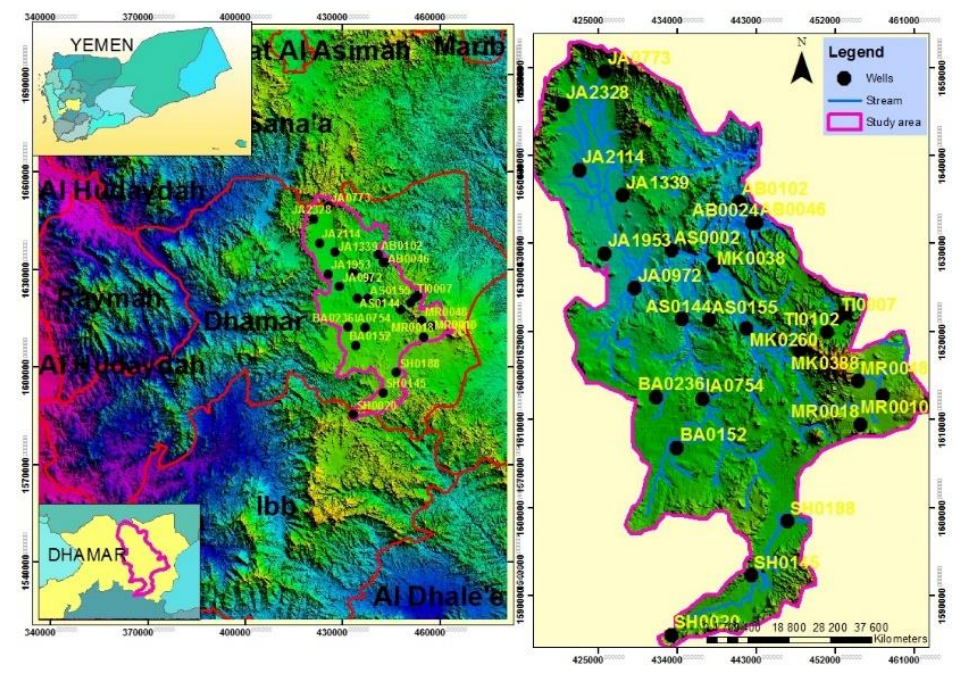

Figure 1. Study area and samples location 
The climate of the study area is semi-arid. The annual rainfall is $407.8 \mathrm{~mm}$, the maximum rainfall was $148.2 \mathrm{~mm}$ in June and the minimum was $88.2 \mathrm{~mm}$ in January during the period from 1999-2016. While the average monthly temperature varied from $21.4^{\circ} \mathrm{C}$ in December $-27.7^{\circ} \mathrm{C}$ in June for the same period (Al-Aizari et al., 2017). The geology of the study area comprises Quaternary alluvium, Tertry, Quaternary volcanic formations. Rhyolites, tuffs and ignimbrite ash-flow with occasional granite intrusions. The available hydrology data show that the main aquifers in Dhamar are Tertiary, Volcanic and Quaternary deposits. Groundwater subtraction through pumping wells in Quaternary deposits is more than Tertiary Volcanic. The outputs of this research are are identifying the productive aquifers and dominant fissure in the north-northeast of the study region (Geukens, 1966; Chiesa, 1983; Overstreet et al., 1985; Al-Kohlani, 2009).

\section{Data sampling}

A total of 27 well representing the Dhamar basin were selected in our study Table 1,14 groundwater samples were collected from each well in May 2009. These data have not been published earlier. The survey was carried out as part of a national program to monitor groundwater resources at a large number of locations nationwide. Since 2009 similar surveys have been carried out at other locations, which are not relevant for this study since samples were taken in different aquifers. It is not a common practice of this Government Department to publish the data they collect in response to governmental regulations. The samples were collected after pumping for 10 minutes, clean and dry polyethylene bottles are used for sample collection. The samples are tagged and stored in a refrigerator before the analysis (Girard, 1975). All samples were transported at temperature $4^{\circ} \mathrm{C}$ in portable coolers to the general agricultural research laboratory at Dahmer where the analyzes are carried out. Physio-chemical parameters were carried out EC, $\left(\mathrm{Ca}^{2+}\right),\left(\mathrm{Mg}^{2+}\right),\left(\mathrm{Na}^{+}\right),\left(\mathrm{K}^{+}\right),\left(\mathrm{HCO}_{3}{ }^{-}\right),\left(\mathrm{Cl}^{-}\right),\left(\mathrm{SO}_{4}{ }^{2-}\right),\left(\mathrm{NO}_{2}^{-}\right),\left(\mathrm{Fe}_{2}{ }^{+}\right),\left(\mathrm{F}^{-}\right)$and (TH) and then compared with the guidelines admitted by the World Health Organization (WHO, 2003; Al-Asbahi, 2005).

Table 1. The site and the name of the studied well

\begin{tabular}{c|c|c|c|c|c}
\hline No. & Well ID & Site name & No. & Well ID & Site name \\
\hline 1 & AB0102 & Abisiyah & 15 & JA1339 & Jahran \\
2 & AB0024 & Abisiyah & 16 & JA1953 & Jahran \\
3 & AB0046 & Abisiyah & 17 & JA2114 & Jahran \\
4 & AS0144 & Aswad & 18 & JA2328 & Jahran \\
5 & AS0155 & Aswad & 19 & MK0260 & Makhderah \\
6 & AS0002 & Aswad & 20 & MK0038 & Makhderah \\
7 & BA0236 & Balasan & 21 & MK0388 & Makhderah \\
8 & IA0754 & Intervening & 22 & TI0102 & Tinnan \\
9 & MR0010 & Maram & 23 & TI0049 & Tinnan \\
10 & MR0018 & Maram & 24 & TI0007 & Tinnan \\
11 & MR0048 & Maram & 25 & SH0020 & Sherah \\
12 & BA0152 & Balasan & 26 & SH0188 & Sherah \\
13 & JA0773 & Jahran & 27 & SH0145 & Sherah \\
14 & JA0972 & Jahran & & & \\
\hline
\end{tabular}




\section{Chemical analysis}

EC is measured in the field using conductivity meter (Medium Conductivity Session $\mathrm{CEL} / 850$ (HACH). $\mathrm{PH}$ is measured by $\mathrm{pH}-422 . \mathrm{Ca}^{2+}$ and $\mathrm{Mg}^{2+}$ are estimated titrimetrically using $0.02 \mathrm{~N}$ EDTA. $\mathrm{HCO}_{3}{ }^{-}$and $\mathrm{Cl}^{-}$are estimated by $\mathrm{H}_{2} \mathrm{SO}_{4}$ and $\mathrm{AgNO}_{3}$ titration $(0.02 \mathrm{~N})$, respectively. $\mathrm{Na}^{+}$and $\mathrm{K}^{+}$are measured by using a Flame photometer (PFP 7). F-, $\mathrm{Fe}^{2+}$, and $\mathrm{NO}_{2-}$ are measured by the portable data logging spectrophotometer $\mathrm{HACH} \mathrm{DR} / 2400$. This standard method is suggested by the American Public Health Association (WHO, 2003; APHA, 2005) (Table 2).

Table 2. Average physiochemical analyses for the grounds water and compared with YEMEN standards, WHO and Irrigation

\begin{tabular}{c|c|c|c|c|c|cc}
\hline Variable & Unit & Minimum & Maximum & Mean & STDEV & Yemen Standard WHO Guideline \\
\hline $\mathrm{EC}$ & $\mu \mathrm{s} / \mathrm{cm}$ & 312.7 & 1915.8 & 524 & 323.6 & $750-2000$ & $1000-1500$ \\
$\mathrm{pH}$ & - & 5.8 & 9.2 & 7.248 & 0.86 & $6.5-9$ & $6.9-9.2$ \\
$\mathrm{Ca}^{2+}$ & $\mathrm{mg} / 1$ & 8 & 200 & 48.94 & 37.88 & $75-200$ & 200 \\
$\mathrm{Mg}^{2+}$ & $\mathrm{mg} / 1$ & 2.4 & 43.6 & 7.7 & 7.71 & $30-150$ & 150 \\
$\mathrm{Na}^{+}$ & $\mathrm{mg} / 1$ & 14.6 & 190 & 87.28 & 51.88 & $200-400$ & 200 \\
$\mathrm{~K}^{+}$ & $\mathrm{mg} / 1$ & 0.8 & 10.7 & 4.27 & 2.597 & $8-12$ & $8-20$ \\
$\mathrm{HCO}^{--}$ & $\mathrm{mg} / 1$ & 97.6 & 463.6 & 227.7 & 83.1 & $150-500$ & \\
$\mathrm{Cl}^{-}$ & $\mathrm{mg} / 1$ & 29 & 335 & 70.9 & 65.7 & $200-600$ & 250 \\
$\mathrm{SO}^{2-}$ & $\mathrm{mg} / 1$ & 20 & 320 & 58.5 & 64.5 & $200-400$ & 250 \\
$\mathrm{NO}_{3}^{--}$ & $\mathrm{mg} / 1$ & 1.50 & 49.70 & 15.64 & 14.68 & $0-50$ & $0-50$ \\
$\mathrm{Fe}^{2+}$ & $\mathrm{mg} / 1$ & 0 & 1.07 & 0.2122 & 0.2409 & $0.3-1$ & 0.3 \\
$\mathrm{~F}^{-}$ & $\mathrm{mg} / 1$ & 0 & 0.09 & 0.01556 & 0.0268 & $0.5-1.5$ & 1.5 \\
$\mathrm{TH}$ & $\mathrm{mg} / 1$ & 40 & 680 & 149.6 & 122.1 & $100-500$ & 500 \\
\hline
\end{tabular}

\section{Geo-statistical analysis}

Statistical analysis was carried out using statistical package for social sciences (Minitab17). The physicochemical analysis for all the samples was analyzed by Pearson's correlation coefficient and principal component analysis. The PCA adopted in this paper is based on normalized and standardized data and exploits the correlation matrix between groundwater quality parameters rather than the covariance matrix (Sabnavis and Patangay, 1998; Van den Brink and Ter Braak, 1999; Singh et al., 2004; Joshi et al., 2009; Khatoon et al., 2013; Chaubey and Patil, 2015).

Interpolation methods fall into two categories, namely: the deterministic method and geostatistical method (Chen and Liu, 2012). Deterministic interpolation methods create surfaces from measured points, based on either the extent of similarity or the degree of smoothing. For instance, Inverse Distance Weighting (IDW), radial basis functions and splines function. The geostatistical interpolation methods such as Kriging method (Davis and Ierapetritou, 2007; Elhag and Bahrawi, 2017) can describe spatial patterns and interpolate the value of a primary variable at unmeasured locations, and quantify the uncertainty or error of estimated surface (Elhag, 2016a).

IDW assumes that the attribute value of unmeasured points is the weighted average of known values of the neighborhood. IDW will use the measured values surrounding the unmeasured locations to predict the values of the unmeasured ones. Those measured values closest to the prediction location will have more influence on the predicted value than those farther away. Thus, IDW assumes that each measured point has a local influence that diminishes with distance. It weights the points closer to the prediction location greater than 
those far away. Maps layout are generated used ARCGIS 13 and AquaChem 2014 (Elhag, 2016a,b; Elhag and Bahrawi, 2016).

\section{Sodium Adsorption Ratio}

Sodium adsorption ratio (SAR) a formula used to evaluate salinity hazard and whether the water quality of the Groundwater Suitable or not acceptability for irrigation uses Lesch and Suarez (2009) (Table 3). SAR is calculated from the $\mathrm{Na}^{+}, \mathrm{Ca}^{++}$, and $\mathrm{Mg}^{+}$using the following equation.

$$
\mathrm{SAR}=\mathrm{Na} /[(\mathrm{Ca}+\mathrm{Mg}) / 2]^{1 / 2}
$$

where $\mathrm{Na}^{+}, \mathrm{Ca}^{++}$, and $\mathrm{Mg}^{++}$are the concentrations expressed in milli-equivalents per litre (meq/L).

Table 3. Irrigational Water Classification

\begin{tabular}{c|c}
\hline SAR (epm) & Classification \\
\hline$<10$ & Excellent \\
\hline $10-18$ & good \\
\hline $18-26$ & Permissible \\
\hline$>26$ & Unsuitable \\
\hline
\end{tabular}

It depend on the distribution of SAR as described in Table 3 and Figure 2 indicating that all wells suitable for irrigation. In relation to the hazardous effects of sodium adsorption ratio, the irrigation water quality rating is given in Table 3.

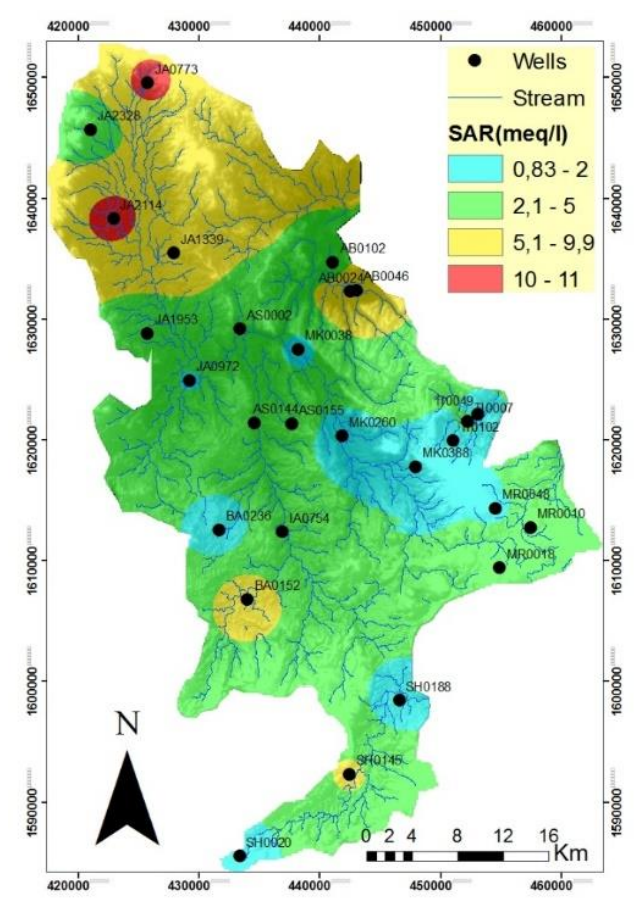

Figure 2. Distribution of SAR 


\section{Result and Discussions}

The physicochemical analysis of 27 well and evaluating suitability for drinking water and irrigation purposes are summarized in Table 2.

The tested physiochemical parameters of the designated water wells in accordance with Yemen Maximum Allowable Unit (MAU) and compared to the World Health Organization (WHO) are cross-referenced in Table 2. The range of variation in Yemen standards is quite wide which makes it more difficult to have a fair judge. Generally, one one hand, the tested variables are within or slightly above the MAU. On the other hand, the tested variables are poorly recorded according to WHO.

EC in the collected samples is ranged from 312.7 to $1915.8 \mu \mathrm{s} / \mathrm{cm}$ with an average value of $524 \pm 323.6$. The map shows that the values of EC are within the permissible level except for some areas, mainly (well no. IA0754), in which the EC recorded $1915.8 \mu \mathrm{s} / \mathrm{cm}$. Therefore, it exceeds the WHO permissible level but it still within the level of Yemen standard as in Table 2. The high value of EC in that location is due to contamination from the effluent of wastewater treatment plans (WWTP) as this well located in Mawaheb village. The cartographic map showing the distribution of EC is given in Figure 3. The EC showed strong correlation with $\mathrm{Cl}^{-}$and $\mathrm{SO}_{4}{ }^{2-}(\mathrm{r}=0.94,0.93$, respectively) and good correlation between with $\mathrm{Ca}^{2+} \mathrm{Mg}^{2+}, \mathrm{Na}^{+}$and $\mathrm{TH}(\mathrm{r}=0.76,0.8$, 0.52 and 0.84 , respectively).

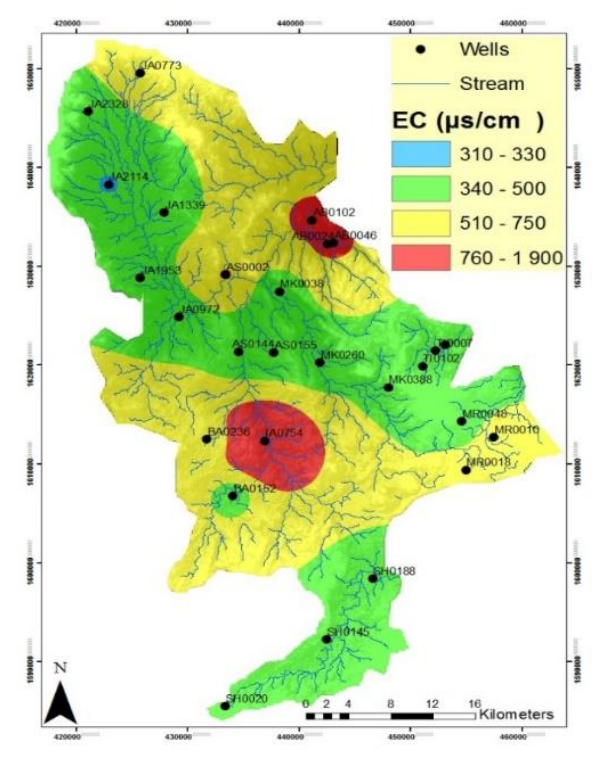

Figure 3. Distribution of EC

$\mathrm{pH}$ is considered as an important ecological factor that provides information on the types of geochemical equilibrium and solubility. From the thematic map (Figure 4), the $\mathrm{pH}$ is ranged from 5.8 to 9.2 so it is within the slandered of Yemen and WHO. The results show that three wells are basic and three well are acidic. The basic wells are Abisiyah (well no. ABS46, $\mathrm{pH}=9.2$ ), Balasan (well no. BB56, $\mathrm{pH}=9.2$ ) and Jahran (well no. QJB511, $\mathrm{pH}=8.9$ ). The three acidic wells are 6.3, 5.8 and 6.1 for the intervening area (well no. IA0754 $\mathrm{pH}=6.3$ ), Maram (well no. MR0018, $\mathrm{pH}=5.8$ ) and Jahran (well no. JA1953, $\mathrm{pH}=6.1$ ). $\mathrm{pH}$ showed negative correlation with all of parameters except $\mathrm{Na}^{+} \mathrm{Cl}^{-}$and $\mathrm{Fe}^{2+}(\mathrm{r}=0.020,00$ and 0.34 , respectively). 


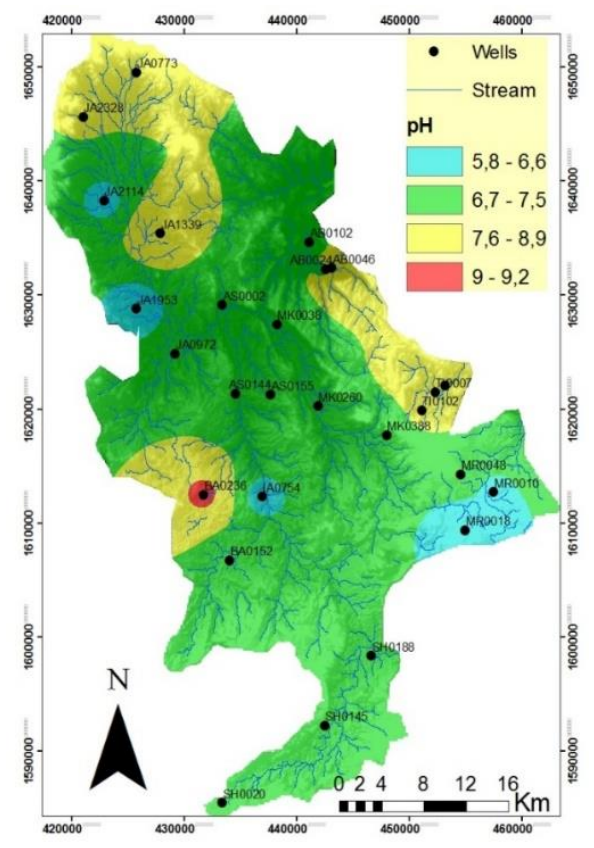

Figure 4. Distribution of $p H$

$\mathrm{Na}^{+}$varies from 14.6 to $190 \mathrm{mg} / \mathrm{l}$ with an average value of $87.28 \pm 51.88$. The high concentration of sodium in water makes it unsatisfactory for use in irrigation purposes. The concentration of sodium in all samples are found to be within the permissible level of WHO and Yemen Standers Table 2. However, in well no AB0046, the concentration of sodium found to be near to the permissible level which is $190 \mathrm{mg} / \mathrm{l} . \mathrm{Na}^{+}$has good correlation with $\mathrm{Cl}^{-}$and $\mathrm{SO}_{4}{ }^{2-}(\mathrm{r}=0.60,0.53)$, demonstrated in Figure 5.

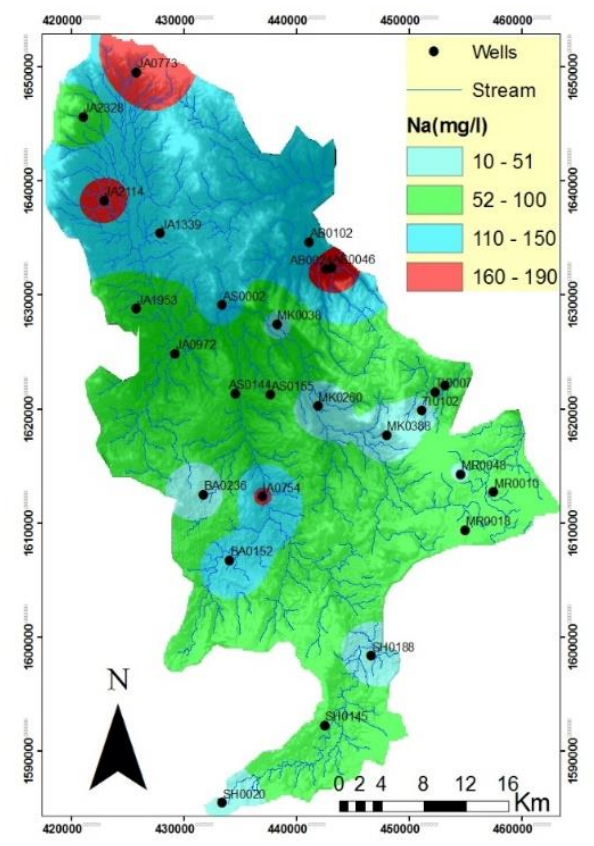

Figure 5. Distribution of $\mathrm{Na}$ 
The concentration of $\mathrm{K}^{+}$various from 0.8 to $10.7 \mathrm{mg} / \mathrm{l}$ with an average value of $4.27 \pm 2.59$. The concentration of potassium in all samples is found to be within the permissible level (Table 2$). \mathrm{K}^{+}$has good correlation with $\mathrm{F}^{-},(\mathrm{r}=0.53)$, demonstrated in Figure 6.

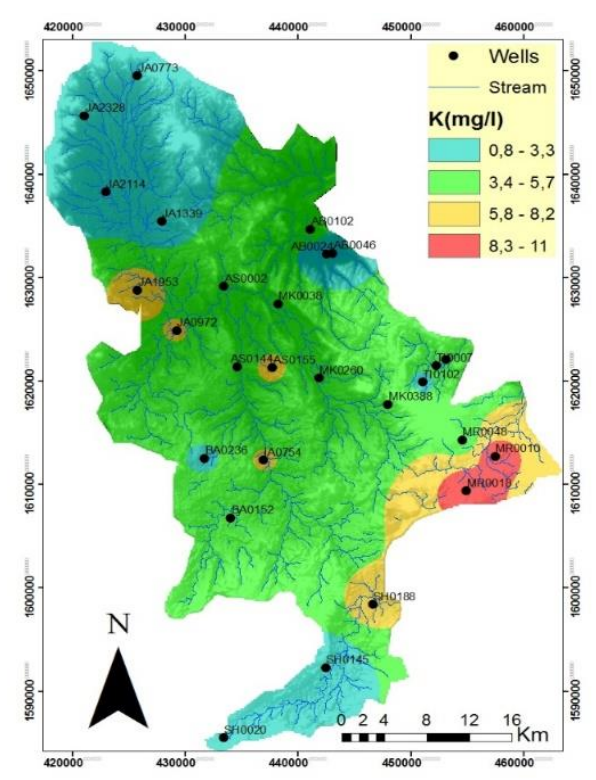

Figure 6. Distribution of $K$

The $\mathrm{Mg}^{2+}$ values range from 2.4 to $43.6 \mathrm{mg} / \mathrm{l}$ with an average value of $7.7 \pm 7.71$, the presence of $\mathrm{Mg}^{2+}$ in water generally does not have any health hazards to humans. The concentrations of $\mathrm{Mg}^{2+}$ in all samples are found to be within the permissible level in Table 2 and Figure 7. $\mathrm{Mg}^{2+}$ is strong correlated with $\mathrm{TH}(\mathrm{r}=0.98)$ and with $\mathrm{Ca}^{2+}$ with $\mathrm{Mg}^{2+}, \mathrm{Cl}^{-}$and $\mathrm{SO}_{4}{ }^{2-}(\mathrm{r}=0.81,0.59$ and 0.64$)$, while it is good correlated with $\mathrm{Cl}^{-}$and $\mathrm{SO}_{4}{ }^{2-}(\mathrm{r}=0.78,0.76)$ respectively.

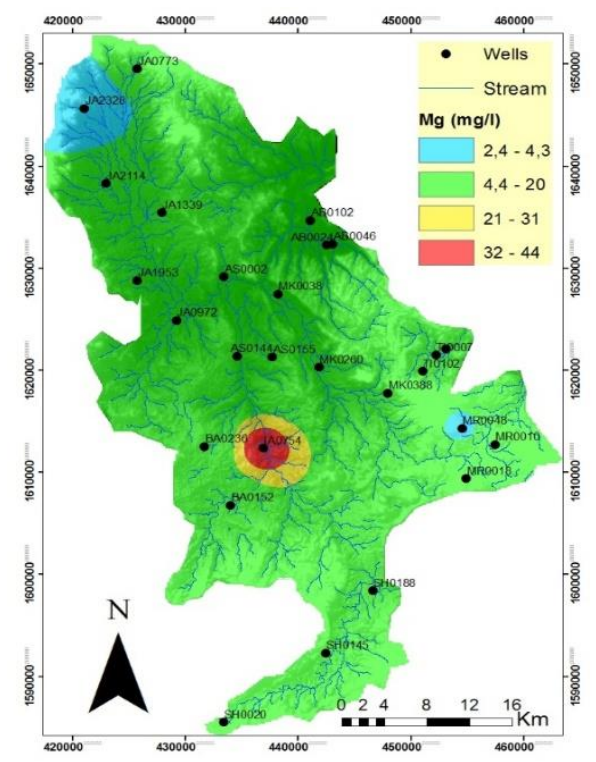

Figure 7. Distribution of $M g$ 
$\mathrm{Ca}^{2+}$ ranges from 8 to $200 \mathrm{mg} / \mathrm{l}$ with an average value of $48.94 \pm 37.88$. the presence of $\mathrm{Ca}^{2+}$ in water does not have health hazards to humans. $\mathrm{Ca}^{2+}$ values are within the permissible level in all samples except in the intervening area (well no. IA0754). This may be attributed to pollution by wastewater (Figure 8). $\mathrm{Ca}^{2+}$ shows strong correlation with $\mathrm{TH},(\mathrm{r}=0.98)$ and good correlation with $\mathrm{Mg}^{2+}, \mathrm{Cl}^{-}$and $\mathrm{SO}_{4}{ }^{2-}(\mathrm{r}=0.81,0.59$ and $0.64)$ respectively.

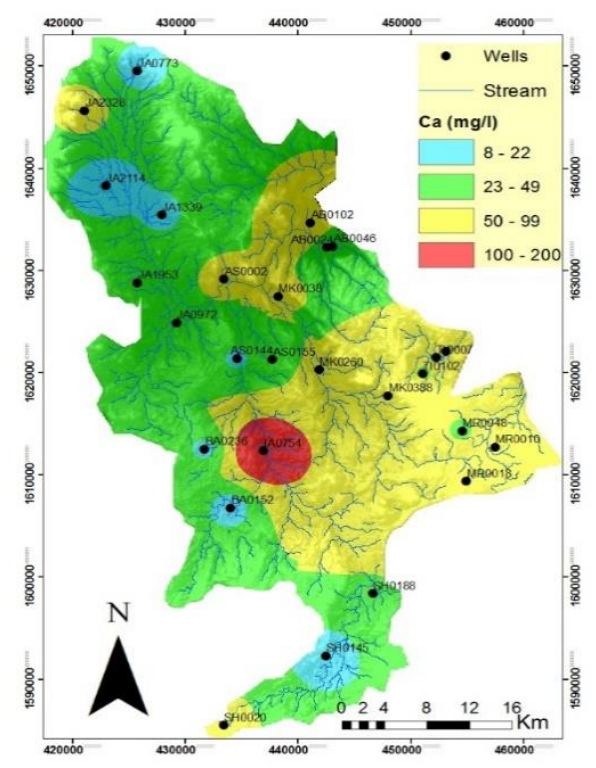

Figure 8. Distribution of $\mathrm{Ca}$

$\mathrm{SO}_{4}{ }^{2-}$ values various from $20-320 \mathrm{mg} / \mathrm{l}$ with an average value of $58.5 \pm 64.5$. The concentration of sulfate in all locations are within the permissible limit except the intervening area (well no. IA0754) where the sulfate value $320 \mathrm{mg} / \mathrm{l}$. The $\mathrm{SO}_{4}{ }^{2-}$ was has a good correlation between $\mathrm{SO}_{4}{ }^{2-}$ with $\mathrm{TH}(\mathrm{r}=0.98)$ as is illustrated in Figure 9.

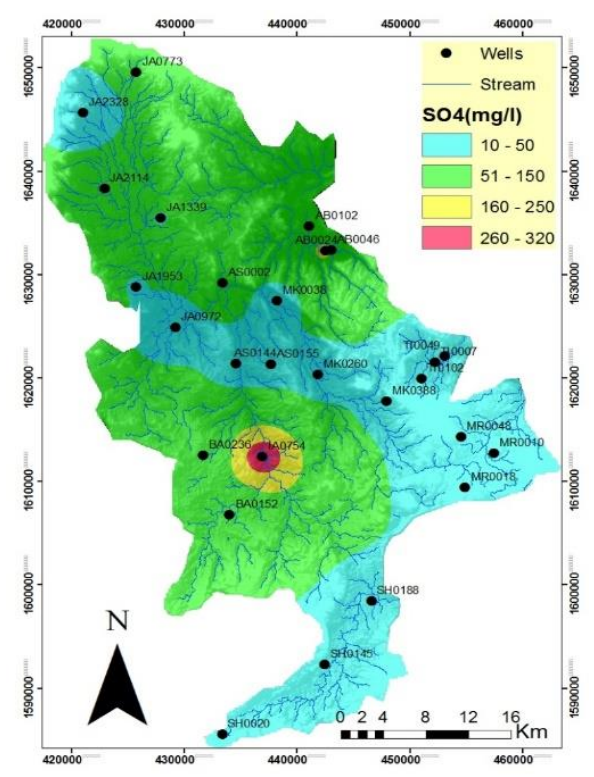

Figure 9. Distribution of $\mathrm{SO}^{--}$ 
The $\mathrm{HCO}_{3}{ }^{-}$varies from 97.6 to $463.6 \mathrm{mg} / \mathrm{l}$ with an average value of $227.7 \pm 83.1$. The concentration of bicarbonate in all samples are found to be within the permissible limit (Figure 10). The $\mathrm{HCO}_{3}{ }^{-}$has strong correlation with $\mathrm{SO}_{4}{ }^{2-}(\mathrm{r}=0.98)$.

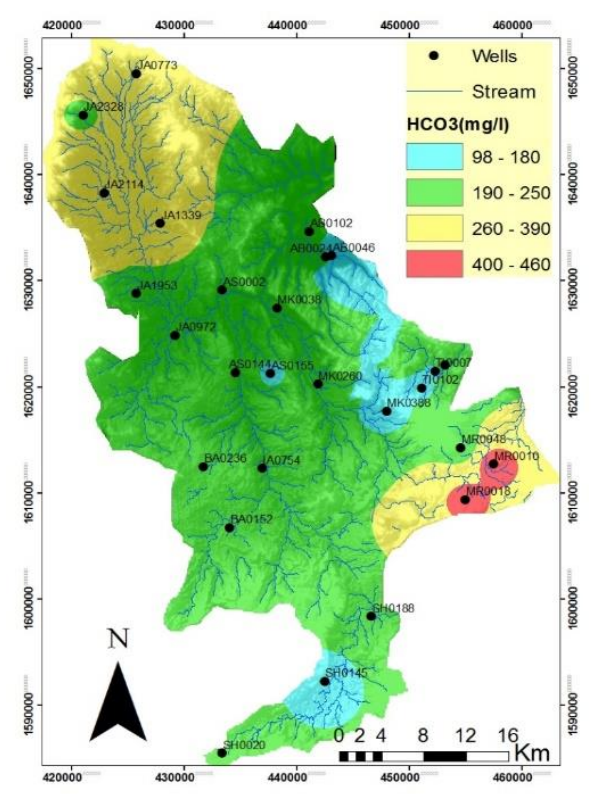

Figure 10. Distribution of $\mathrm{HCO}_{3}$

WHO reported that atmosphere, legumes, plant debris, and animal excreta are the main source of water nitrate, alongside with the domestic water, sewage, septic tanks. Anionic and solubility of $\mathrm{NO}_{3}^{--}$can also affect the concentration of $\mathrm{NO}_{3}^{--}$in groundwater. In Yamen $\mathrm{NO}_{3}^{--}$varies from 0.01 to $0.453 \mathrm{mg} / \mathrm{l}$ with an average value of $227.7 \pm 83.1$. The concentrations of nitrates in all samples are found to be within the permissible limit (Table 2), and its distribution in Figure11.

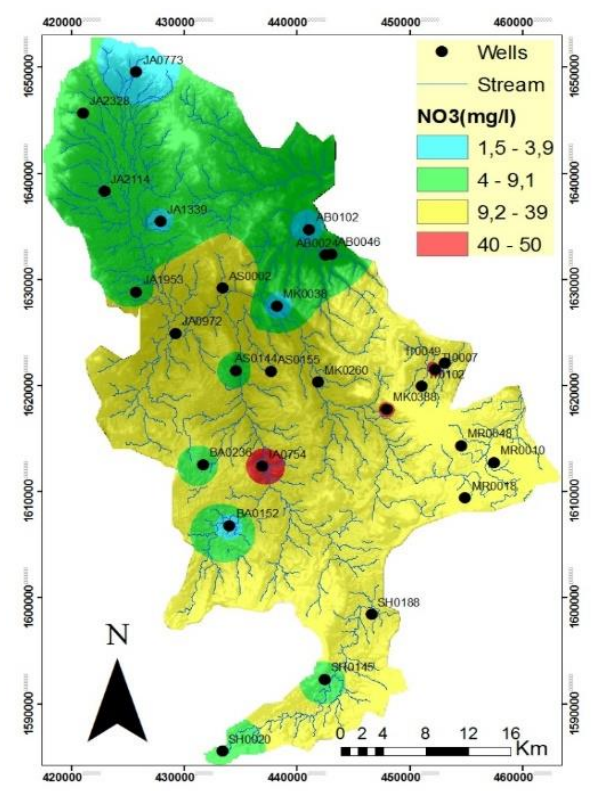

Figure 11. Distribution of $\mathrm{NO}_{3}^{--}$ 
The $\mathrm{F}^{-}$values various from 0 to $0.09 \mathrm{mg} / \mathrm{l}$ with an average value of $0.01556 \pm$ 0.0268 . Fluoride concentration is within the permissible level in all locations. Fluoride above permissible level may cause mottled enamel of teeth and skeleton deformity. The cartographic map of $\mathrm{F}^{-}$is given in Table 2 and demonstrated in Figure 12.

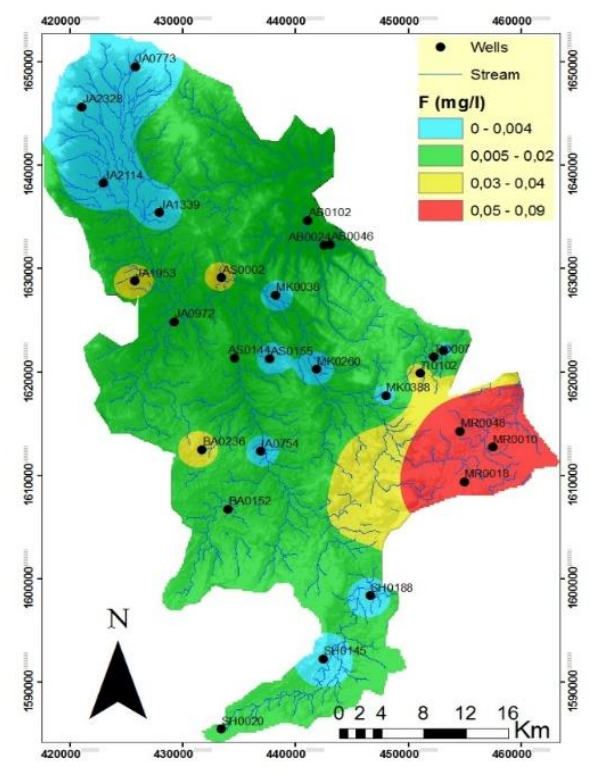

Figure 12. Distribution of $F$

$\mathrm{Fe}^{2+}$ concentration are varied from 0 to $1.07 \mathrm{mg} / \mathrm{l}$ with an average value of $0.2122 \pm 0.2409$. From the cartographic map (Figure 13), iron exceeded the permissible level in some wells Tinnan (TI0102), Tinnan (TI0007), Sherah (SH0188), and Jahran (JA1339). In the case of Tinnan (TI0102) and Jahran (JA1339) this may be attributed to strains of oxides and hydroxides on laundry, sanitary and plumbing textures. At concentration above $0.5 \mathrm{mg} / 1$, iron cause an unpleasant taste (Table 2).

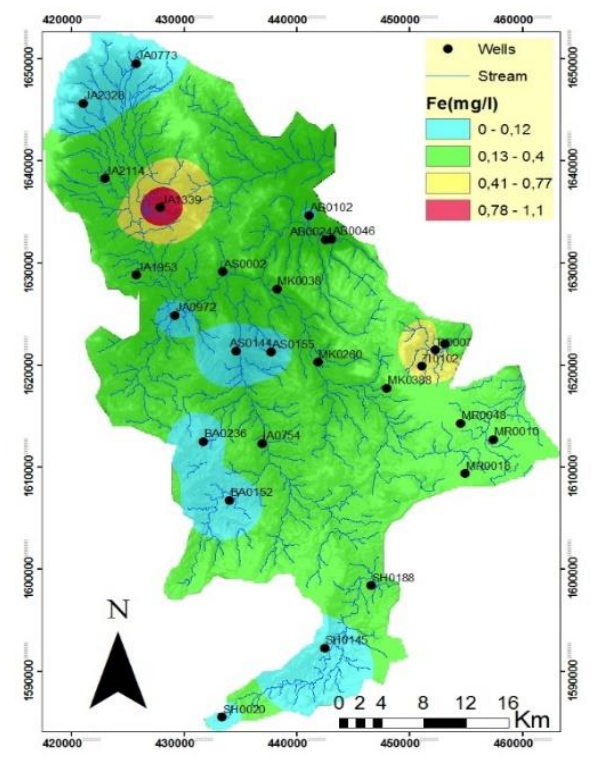

Figure 13. Distribution of $\mathrm{Fe}^{2+}$ 
The $\mathrm{TH}$ values range from 40 to $680 \mathrm{mg} / \mathrm{l}$ with an average value of $149.6 \pm 122.1$ (Figure 14). All samples are within the permissible values as in Table 1 except well no. IA0754 has a comparatively high TH value of $680 \mathrm{mg} / \mathrm{l}$.

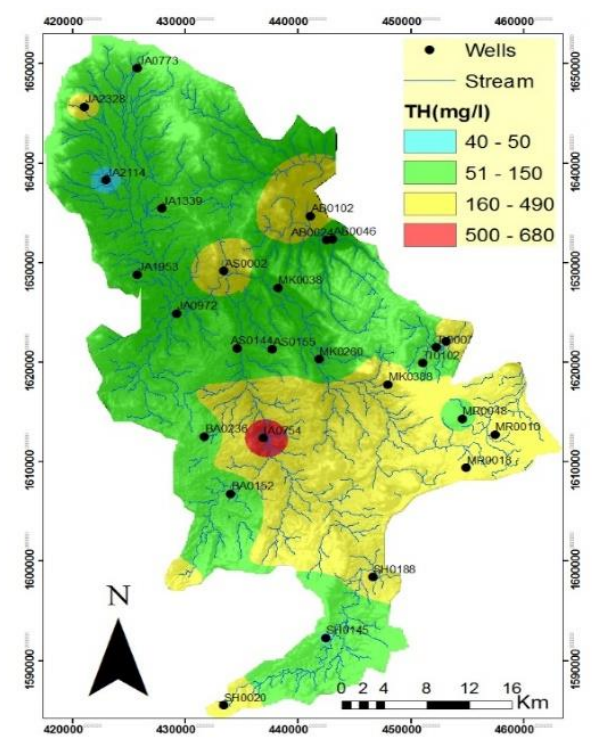

Figure 14. Distribution of TH

$\mathrm{Cl}^{-}$is an important indicator of the contamination of groundwater by wastewater. The $\mathrm{Cl}^{-}$values range from 29 to $335 \mathrm{mg} / \mathrm{l}$ with an average value of $70.9 \pm 65.7$. The permissible limit of $\mathrm{Cl}^{-}$in drinking water for WHO guideline is $250 \mathrm{mg} / \mathrm{l}$, while it is $600 \mathrm{mg} / \mathrm{l}$ for Yemeni Standards. The concentrations of $\mathrm{Cl}^{-}$are within the permissible limit in all locations, except the intervening area (well no. IA0754) where the chloride value is $335 \mathrm{mg} / \mathrm{l}$. The reason for high chloride in that well is due to the contamination of groundwater from effluent as discussed earlier. The cartographic map of $\mathrm{Ca}^{2+}$ is given in Figure 15. The $\mathrm{Cl}^{-}$has a strong correlation with $\mathrm{SO}_{4}{ }^{2-}(\mathrm{r}=0.98)$.

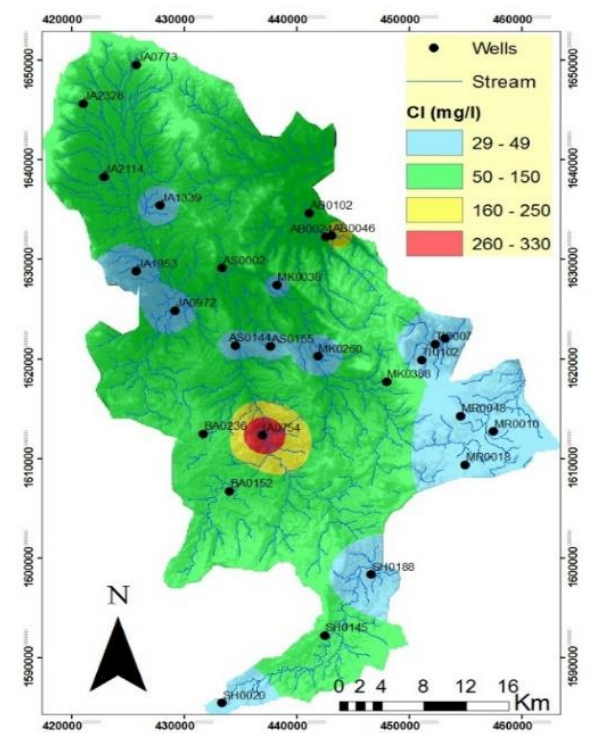

Figure 15. Distribution of $\mathrm{Cl}$ 
Correlation analysis a widely used between variable, the correlation between two variables is the simple correlation that indicates the sufficiency of one variable to predict the other one (Sedgwick, 2012). This coefficient s used to determine the correlation between variables when the dependent $(\mathrm{x})$ is only influenced by the independent $(\mathrm{y})$ and vice versa (Benesty et al., 2009). Table 4 displayed the values of the correlation coefficients between the parameters. Strong correlations $r>0.9$ and good $r=0.5-0.9$.

Table 4. Correlation matrix of all studied parameters

\begin{tabular}{c|ccccccccccccc}
\hline & $\mathbf{E C}$ & $\mathbf{p H}$ & $\mathbf{C a}^{2+}$ & $\mathbf{M g}^{2+}$ & $\mathbf{N a}^{+}$ & $\mathbf{K}^{+}$ & $\mathbf{H C O}_{3}{ }^{-}$ & $\mathbf{C l}^{-}$ & $\mathbf{S O}_{4}{ }^{2-}$ & $\mathbf{N O}^{-}$ & $\mathbf{F e}^{2+}$ & $\mathbf{F}$ & $\mathbf{T H}$ \\
\hline $\mathbf{E c}$ & 1.00 & & & & & & & & & & & & \\
$\mathbf{p H}$ & -0.16 & 1.00 & & & & & & & & & & \\
$\mathbf{C a}^{2+}$ & 0.76 & -0.45 & 1.00 & & & & & & & & & \\
$\mathbf{M g}^{2+}$ & 0.88 & -0.35 & 0.81 & 1.00 & & & & & & & & \\
$\mathbf{N a}^{+}$ & 0.52 & 0.02 & 0.01 & 0.29 & 1.00 & & & & & & & & \\
$\mathbf{K}^{+}$ & 0.14 & -0.56 & 0.44 & 0.33 & -0.27 & 1.00 & & & & & & & \\
$\mathbf{H C O}^{-}$ & 0.10 & -0.32 & 0.14 & 0.15 & 0.28 & 0.42 & 1.00 & & & & & & \\
$\mathbf{C l}^{-}$ & 0.94 & 0.00 & 0.59 & 0.78 & 0.60 & -0.10 & -0.13 & 1.00 & & & & & \\
$\mathbf{S O}_{4}{ }^{2-}$ & 0.93 & -0.09 & 0.64 & 0.76 & 0.53 & -0.06 & -0.06 & 0.91 & 1.00 & & & & \\
$\mathbf{N O}_{3}{ }^{-}$ & 0.29 & -0.16 & 0.58 & 0.43 & -0.24 & 0.38 & -0.13 & 0.21 & 0.17 & 1.00 & & & \\
$\mathbf{F e}^{2+}$ & -0.07 & 0.34 & 0.04 & -0.04 & 0.01 & -0.12 & 0.07 & -0.12 & -0.04 & 0.27 & 1.00 & & \\
$\mathbf{F}$ & -0.01 & -0.25 & 0.13 & -0.02 & -0.09 & 0.53 & 0.48 & -0.18 & -0.19 & 0.20 & -0.02 & 1.00 & \\
$\mathbf{T H}$ & 0.84 & -0.43 & 0.98 & 0.91 & 0.12 & 0.43 & 0.17 & 0.67 & 0.71 & 0.55 & 0.02 & 0.12 & 1.00 \\
\hline
\end{tabular}

\section{Principal Component Analysis}

The principal component analysis is a multidimensional statistical method that can be used in the interpretation of a data matrix. This method, by looking for the reference directions of elongation of a multidimensional point cloud (eigenvalues), summarizes the information by projecting the point cloud on its preferential directions (factorial axes). Factors are linear combinations of the starting variables. Each variable contributing to the factor intervenes with a coefficient called "eigenvector" (Sabnavis and Patangay, 1998; Bahrawi et al., 2016; Elhag, 2016b).

Principal component analysis (PCA) for the groundwater allows determining its chemical characteristics, and their overall variations (factors). We select only the first two factors as they express $63.473 \%$ of the total variance. The analysis of the variables shows in Tables 5, 6 and Figures 16, 17. The Factor 1 expresses $42.748 \%$ of the total factors and wells that correlated with the variables, these variables are conductivity, sodium, nitrates, chloride, calcium, sulfate, magnesium and Total hardens. While factor 2 expresses $20.725 \%$ of the total factors, these variables include bicarbonates, iron, fluoride, and potassium (Figures 18 and 19).

Table 5. Total variation explained by all parameter

\begin{tabular}{l|c|c|c|c|c|c|c|c|c|c|c|c|c}
\hline & F1 & F2 & F3 & F4 & F5 & F6 & F7 & F8 & F9 & F10 & F11 & F12 & F13 \\
\hline Eigenvalue & 5.557 & 2.6943 & 1.62 & 1.2571 & 0.654 & 0.4182 & 0.3071 & 0.2483 & 0.129 & 0.0832 & 0.023 & 0.008 & 0.0033 \\
Proportion & 0.427 & 0.207 & 0.12 & 0.097 & 0.05 & 0.032 & 0.024 & 0.019 & 0.01 & 0.006 & 0.002 & 0.001 & 0 \\
Cumulative & 0.427 & 0.635 & 0.76 & 0.856 & 0.906 & 0.938 & 0.962 & 0.981 & 0.991 & 0.997 & 0.999 & 1 & 1 \\
\hline
\end{tabular}


Table 6. Coefficient of centered variables reduced in the linear equation of the principal axes

\begin{tabular}{c|c|c}
\hline Variable & PC1 & PC2 \\
\hline $\mathbf{E C}$ & 0.404 & 0.144 \\
$\mathbf{p H}$ & -0.158 & 0.357 \\
$\mathbf{T H}$ & 0.403 & -0.116 \\
$\mathbf{H C O}^{-}$ & 0.064 & -0.292 \\
$\mathbf{C l}$ & 0.356 & 0.296 \\
$\mathbf{F}$ & 0.027 & -0.417 \\
$\mathbf{N O}_{3}$ & 0.198 & -0.215 \\
$\mathbf{S O}^{2-}$ & 0.361 & 0.263 \\
$\mathbf{C a}^{2+}$ & 0.379 & -0.155 \\
$\mathbf{M g}^{2+}$ & 0.4 & -0.004 \\
$\mathbf{N a}^{+}$ & 0.155 & 0.311 \\
$\mathbf{K}^{+}$ & 0.14 & -0.504 \\
$\mathbf{F e}^{2+}$ & -0.02 & 0.027 \\
\hline
\end{tabular}

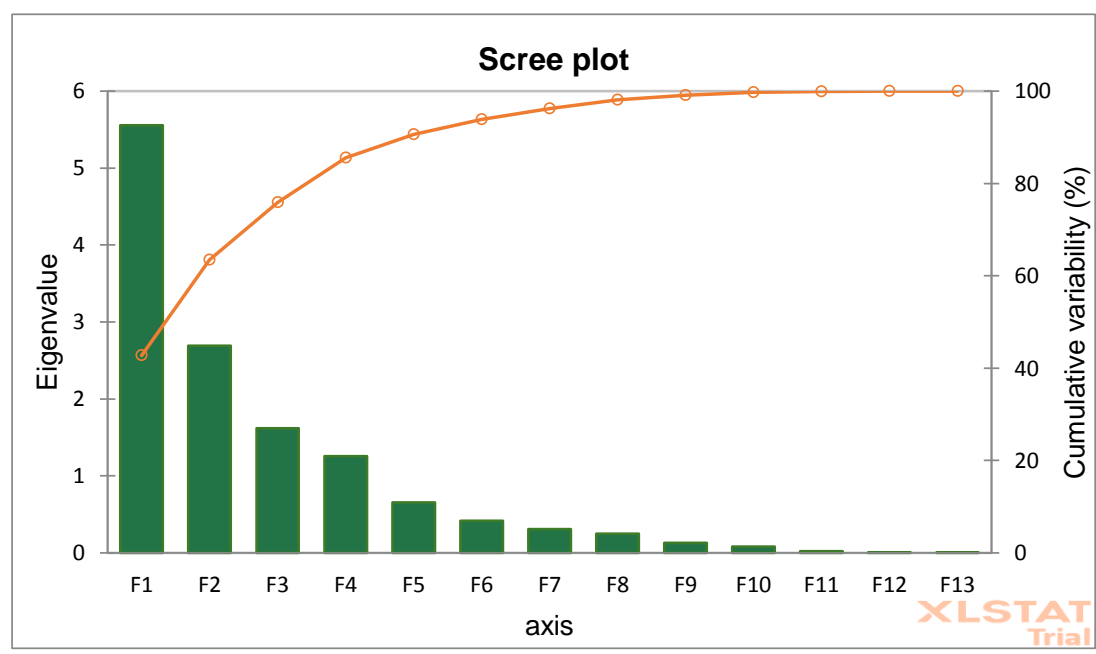

Figure 16. Scree plot for all samples

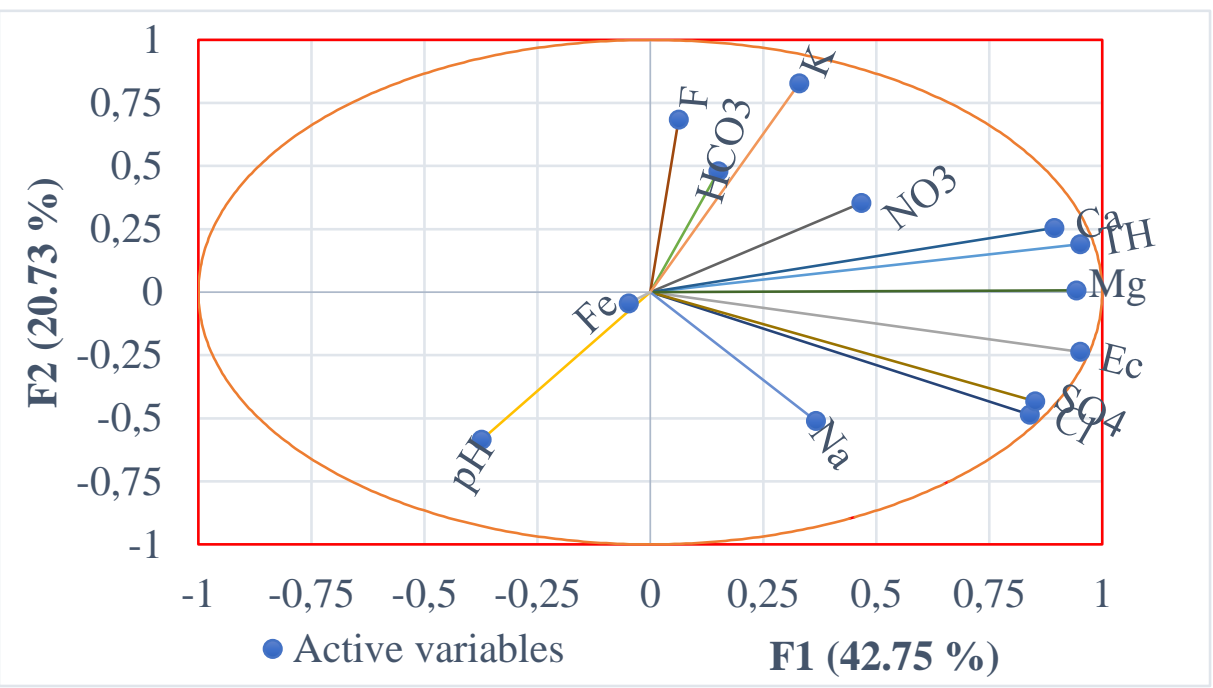

Figure 17. PCA Variables (axes F1 and F2: 63.47\%)

APPLIED ECOLOGY AND ENVIRONMENTAL RESEARCH 18(1):625-644.

http://www.aloki.hu • ISSN 15891623 (Print) • ISSN1785 0037 (Online) DOI: http://dx.doi.org/10.15666/aeer/1801_625644

(c) 2020, ALÖKI Kft., Budapest, Hungary 


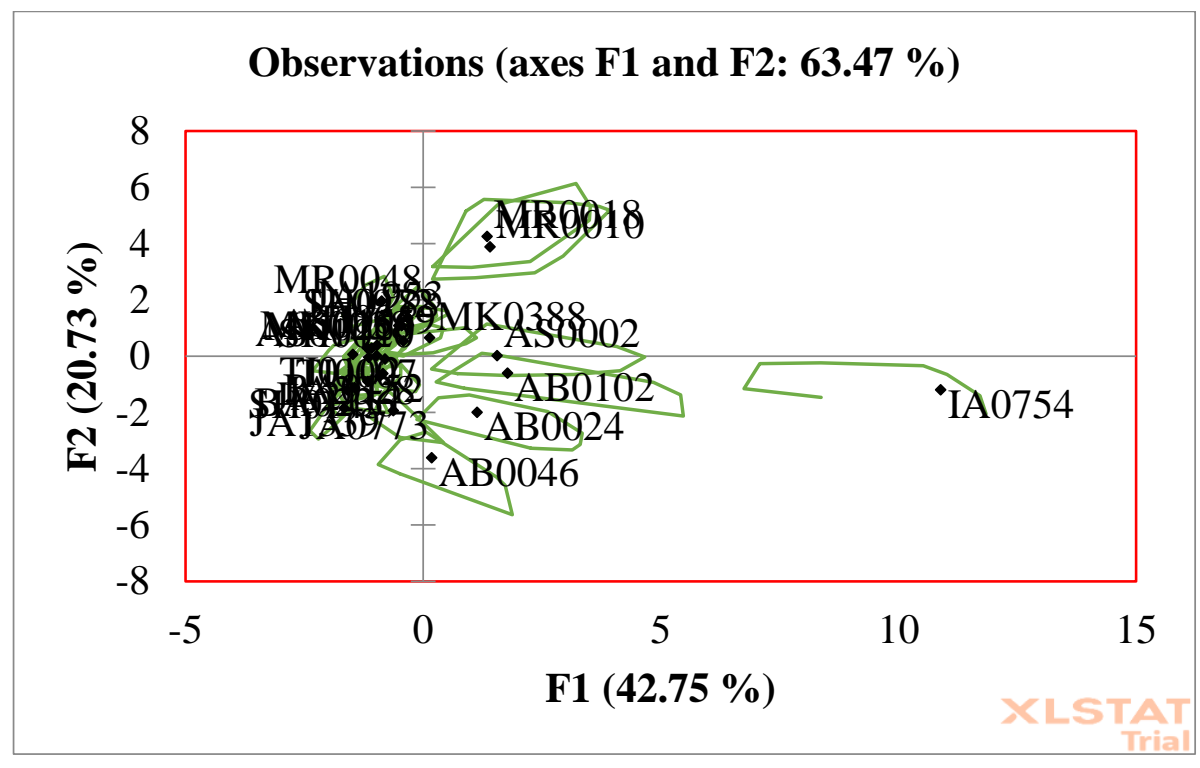

Figure 18. Projection of wells on the F1-F2 factorial plane

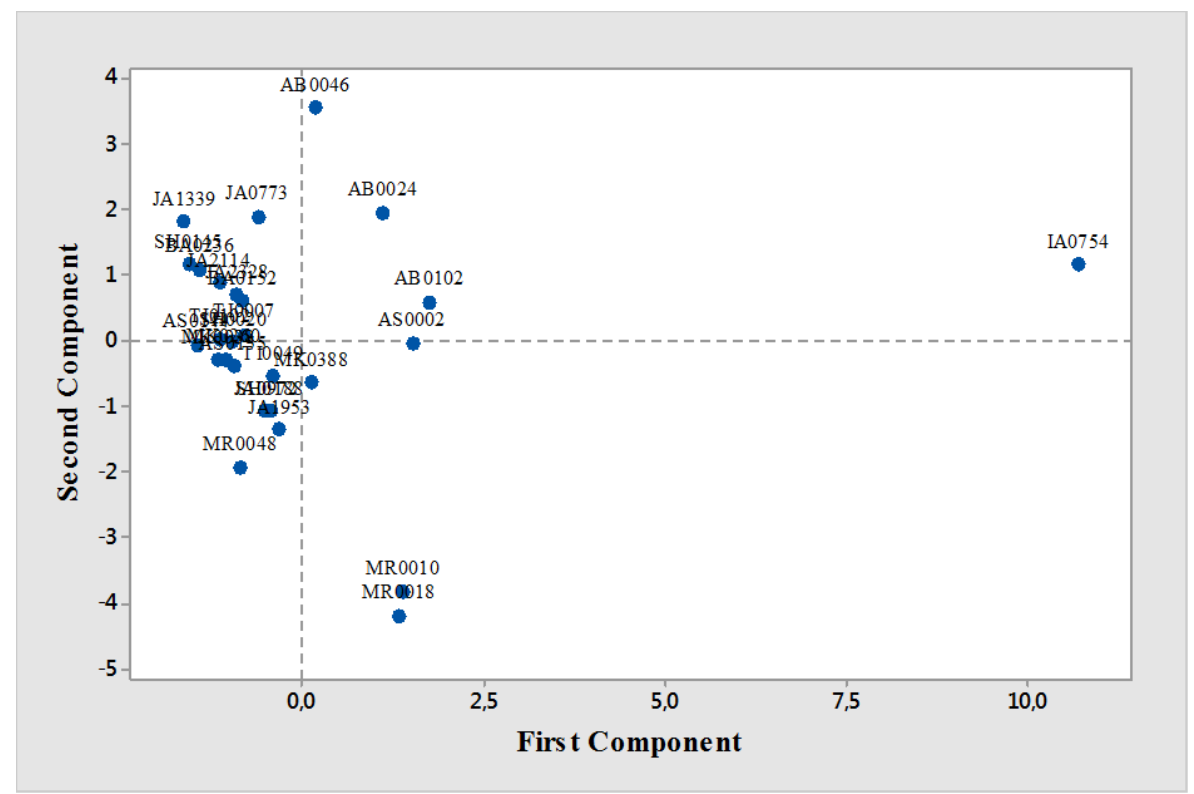

Figure 19. A score of all the samples on the plan

A piper diagram is a graphical representation of the chemistry of water samples. The cations and anions are shown by separate ternary plots. The apexes of the cation plot are calcium, magnesium, and sodium plus potassium cations. The piper diagram was preferred because of its accuracy in the identification of the water samples and the dominant component in the water chemistry (Piper, 1944; Elhag et al., 2019). Generally, the samples are showing different constituents of water as shown in Table 7 and Figure 20. This indicates that the source's groundwater of these wells is different. The differences in compositions of the water are attributed to that the geology of the Dhamar area is generally volcanic and basaltic rock. However, some areas such as Jahran are having alluvial deposits. 
Table 7. Chemical composition of water samples in various locations

\begin{tabular}{|c|c|c|c|}
\hline No. & Well ID & Site name & Chemical Composition \\
\hline 1 & AB0102 & Abisiyah & $\mathrm{Na}-\mathrm{Ca}-\mathrm{HCO} 3-\mathrm{Cl}$ \\
\hline 2 & AB0024 & Abisiyah & $\mathrm{Na}-\mathrm{Ca}-\mathrm{SO} 4-\mathrm{HCO} 3$ \\
\hline 3 & AB0046 & Abisiyah & $\mathrm{Na}-\mathrm{Cl}-\mathrm{SO} 4$ \\
\hline 4 & AS0144 & Aswad & $\mathrm{Na}-\mathrm{HCO} 3-\mathrm{Cl}$ \\
\hline 5 & AS0155 & Aswad & $\mathrm{Na}-\mathrm{Ca}-\mathrm{HCO} 3-\mathrm{Cl}$ \\
\hline 6 & AS0002 & Aswad & $\mathrm{Na}-\mathrm{Ca}-\mathrm{HCO} 3-\mathrm{Cl}$ \\
\hline 7 & BA0236 & Balasan & HCO3-Cl-SO4 \\
\hline 8 & IA0754 & Intervening & $\mathrm{Ca}-\mathrm{Na}-\mathrm{Cl}-\mathrm{SO} 4$ \\
\hline 9 & MR0010 & Maram & $\mathrm{Ca}-\mathrm{Na}-\mathrm{HCO} 3$ \\
\hline 10 & MR0018 & Maram & $\mathrm{Ca}-\mathrm{Na}-\mathrm{HCO} 3$ \\
\hline 11 & MR0048 & Maram & Ca-Na-HCO3 \\
\hline 12 & BA0152 & Balasan & $\mathrm{Na}-\mathrm{HCO} 3-\mathrm{Cl}-\mathrm{SO} 4$ \\
\hline 13 & JA0773 & Jahran & Mg-Na-HCO3 \\
\hline 14 & JA0972 & Jahran & $\mathrm{Ca}-\mathrm{Na}-\mathrm{HCO} 3$ \\
\hline 15 & JA1339 & Jahran & Na-HCO3 \\
\hline 16 & JA1953 & Jahran & $\mathrm{Na}-\mathrm{Ca}-\mathrm{HCO} 3$ \\
\hline 17 & JA2114 & Jahran & $\mathrm{Na}-\mathrm{HCO} 3-\mathrm{Cl}$ \\
\hline 18 & JA2328 & Jahran & $\mathrm{Na}-\mathrm{Ca}-\mathrm{HCO} 3-\mathrm{Cl}$ \\
\hline 19 & MK0260 & Makhderah & Ca-Na-HCO3 \\
\hline 20 & MK0038 & Makhderah & $\mathrm{Ca}-\mathrm{Na}-\mathrm{HCO} 3-\mathrm{Cl}$ \\
\hline 21 & MK0388 & Makhderah & $\mathrm{Ca}-\mathrm{Na}-\mathrm{HCO} 3-\mathrm{Cl}$ \\
\hline 22 & TI0102 & Tinnan & $\mathrm{Ca}-\mathrm{Na}-\mathrm{HCO} 3-\mathrm{Cl}$ \\
\hline 23 & TI0049 & Tinnan & $\mathrm{Ca}-\mathrm{Na}-\mathrm{HCO} 3-\mathrm{Cl}$ \\
\hline 24 & TI0007 & Tinnan & $\mathrm{Na}-\mathrm{Ca}-\mathrm{HCO} 3-\mathrm{Cl}$ \\
\hline 25 & SH0020 & Sherah & $\mathrm{Ca}-\mathrm{Na}-\mathrm{HCO} 3-\mathrm{Cl}$ \\
\hline 26 & SH0188 & Sherah & $\mathrm{Ca}-\mathrm{Na}-\mathrm{HCO} 3$ \\
\hline 27 & SH0145 & Sherah & $\mathrm{Na}-\mathrm{HCO} 3-\mathrm{Cl}$ \\
\hline
\end{tabular}
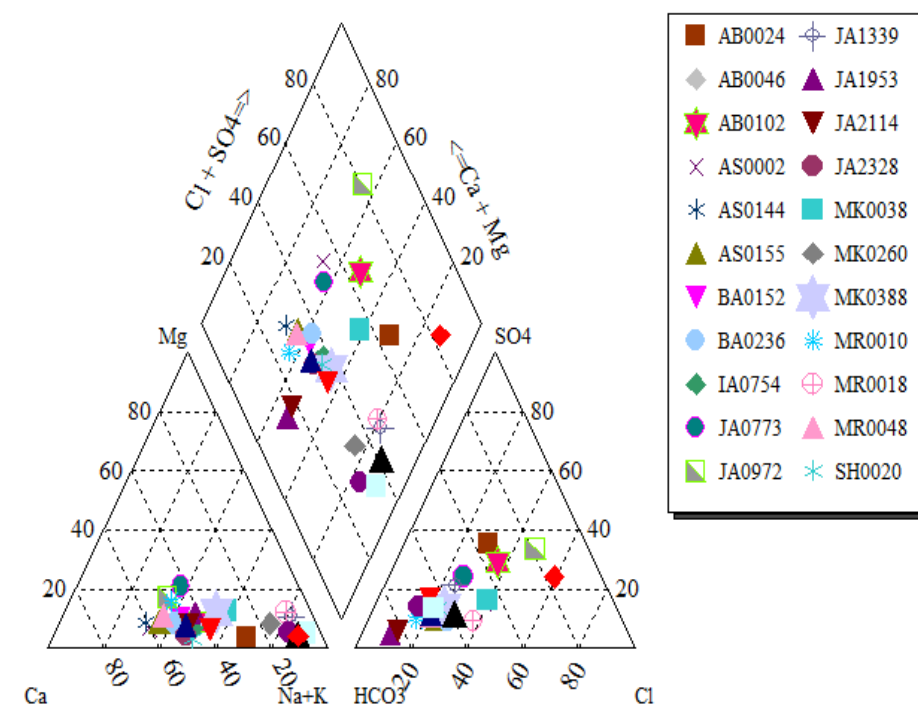

Figure 20. Piper diagram of all samples 
Groundwater is different wells of Abisiyah is a mixture of $\mathrm{Na}^{+}, \mathrm{Ca}^{-}, \mathrm{Cl}^{-} \mathrm{SO}^{-}$and $\mathrm{HCO}_{3}{ }^{-}$. The geological nature of this area is basaltic rocks. Generally, the groundwater aquifers of basaltic rocks have $\mathrm{Na}^{-} \mathrm{Ca}^{-} \mathrm{HCO}_{3}$ composition and any change of this water are due to contamination from human activities or heavy exploitation. The high concentration of $\mathrm{Cl}$ and $\mathrm{SO}_{4}$ without any natural sources indicate human contamination. However, the concentrations of $\mathrm{Cl}$ and $\mathrm{SO}_{4}$ are within the permissible limit of WHO and standard Yamen illustrated in Figure 21.

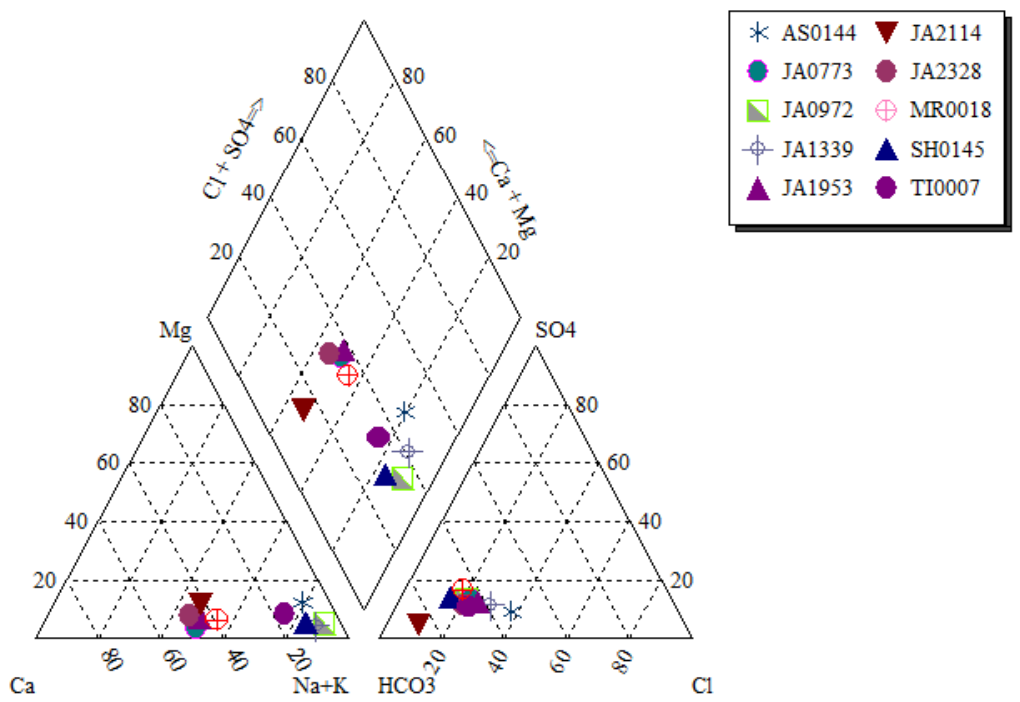

Figure 21. Piper diagram of volcanic aquifer

Predominantly, the water quality parameters used in the current research are varied based on the utilized sample in each rationing. Therefore, the categorization of different quality parameters using principal component analysis will help to examine the indices discrepancies (Yilmaz et al., 2018).

The dynamicity of the water quality monitoring process added further complications to designating mineral-affected wells in a systematic uniform perspective. The use of different quality parameters based on implementing different combinations and/or water samples in the form of water quality parameters evidenced to be more efficient to overcome wells' dynamicity problems (Elhag, 2016b; Bahrawi and Elhag, 2019; Elhag et al., 2019).

Earth is a forceful system that has been affected by natural and anthropological influences. One of the most substantial anthropogenic consequences on the earth are Land Use/Land Cover changes of (LULC) which take place over the earth surface. (Elhag, 2016c, Allam et al., 2019).

The water resources of the coastal region of the Gharb are susceptible to the pollution caused by the emergent industry and urbanization expansion. Certainly, the global economy growth, population density, and infrastructure developments stressed water quality and quantity (Elhag and Bahrawi 2014, Aremu, M. O. et al., 2017, Darwesh et al., 2019). 


\section{Conclusion}

Geographic Information System (GIS), correlation and Principal Component Analysis have been found to be a highly useful technique towards water quality management. The results of this study provide some information that can be useful with respect to groundwater studies. Salinity values are an acceptable level, in spite of the strong water abstraction from the wells in Dhamar plain except for the well no IA0754 that its salinity recorded $1900 \mu \mathrm{S} / \mathrm{cm}$ that is due to contamination from the effluent of wastewater treatment plans (WWTP) as this well located in Mawaheb village. The average salinity values are $524 \mu \mathrm{S} / \mathrm{cm}$ at $25^{\circ} \mathrm{C}$. About $99 \%$ of the wells are classified as suitable for drinking water, and only $1 \%$ of total wells exceed the Yemeni standard for drinking water with respect to the Iron element. All wells are suitable for irrigation purposes. The low TDS was found in the groundwater of the Dhamar area because groundwater drains in igneous rocks (acidic rock), which release a low concentration of major elements. The lower concentrations of $\mathrm{Cl}^{-}$and $\mathrm{SO}_{4}^{--}$are due to an artificial source of pollution by human activities. Generally, groundwater quality is good in Dhamar plain. The presence of nitrates shows that the pollutant penetrates freely from the surface and that because of the hydrodynamic characteristics of the aquifers. The results of the good analysis of Dhamar plain indicates that the type of groundwater is Na-Ca$\mathrm{Cl} / \mathrm{SO}^{4-} \mathrm{HCO}^{3-}$ and $\mathrm{Ca}^{-} \mathrm{Na}^{-} \mathrm{HCO}_{3}{ }^{-} \mathrm{Cl}$, to mixed nature. The study recommended that modeling of groundwater quality in response to growing exploitation, particularly for irrigation. Irrigation leads to the percolation of water with higher salinity, thus potentially harmful for the long term sustainability of groundwater resources. Monitoring should be done more frequently and continuously to ensure timely detection of anomalies.

Acknowledgments. The authors are thankful to National Key Research and Development Program (China's 13th Five Year Plan) "Spatial information service and application demonstration of comprehensive monitoring of urban and rural ecological environment" (2017YFB0503900, 2017YFB0503905), and to the Science and technology cooperation project of Sanya Municipal Institute: Non-Point Source Pollution Risk Identification and Quantitative Assessment for Surface Water Source Using Remote Sensing, (2018YD10) and Hainan Province Natural Science Foundation: Urban Impervious Surface Remote Sensing Extraction and Study on the Characteristics of Multi Temporal and Spatial Evolution, (417218). The authors are also thankful to Renewable Natural Resources Research Center (RNRRC), Dhamar, Yemen, for helping in analyzing the ground water.

\section{REFERENCES}

[1] Al-Aizari, H., Lebkiri, A., Fadli, M., Albaseer, S. S. (2017): Quality assessment of ground water in Dhamar City, Yemen. - International Journal of Environment 6(4): 5671.

[2] Al-Asbahi, Q. Y. A. M. (2005): Water resources information in Yemen. - United Nations Intersecretariat Working Group on Environment Statistics (IWG-ENV), International Work Session on Water Statistics, Vienna (June 20-22), available at: http://unstats. un. org/unsd/environment/envpdf/pap_wasess3a3yemen.

[3] Al-Kohlani, T. A. M. (2009): Geochemistry of thermal waters from Al-Lisi-Isbil geothermal field, Dhamar governorate, Yemen. - Proceedings World Geothermal Congress, Bali, Indonesia. 
[4] Allam, M., Bakr, N., Elbably W., (2019): Multi-temporal assessment of land use/land cover change in arid region based on landsat satellite imagery: Case study in Fayoum Region, Egypt. Remote Sensing Applications: Society and Environment 14: 8-19.

[5] APHA (2005): Standard methods for the examination of water and wastewater. American Public Health Association: Washington, DC, USA.

[6] Aremu, M.O., .Oko O.J., Andrew, C. (2017): Ground water and river quality assessment for some heavy metals and physicochemical parameters in Wukari town, Taraba state, Nigeria. International Journal of sciences. 6 (05): 37-80.

[7] Ayad, W., Kahoul, M. (2016): Evaluation de la qualité physicochimique et bactériologique des eaux de puits dans la région d'El-Harrouch (NE-Algérie) [Assessment of physico-chemical and bacteriological quality of Well water in the region of ElHarrouch (NE-Algeria)]. - Journal of Materials and Environmental Science 7: 12881297.

[8] Bahrawi, J. A., Elhag, M., Aldhebiani, A. Y., Galal, H. K., Hegazy, A. K., Alghailani, E. (2016): Soil Erosion Estimation Using Remote Sensing Techniques in Wadi Yalamlam Basin, Saudi Arabia. - Advances in Materials Science and Engineering Vol. 2016: 9585962.

[9] Bahrawi, J., Elhag, M. (2019): Consideration of seasonal variations of water radiometric indices for the estimation of soil moisture content in erid environment in Saudi Arabia. Applied Ecology and Environmental Research 17(1): 285-303.

[10] Bakraji, E., Karajo, J. (1999): Determination of heavy metals in Damascus drinking water using total reflection X-ray fluorescence. - Atomic Energy Commission, Technical Report.

[11] Benesty, J., Chen, J., Huang, Y., Cohen, I. (2009): Pearson correlation coefficient. Noise reduction in speech processing. Springer Topics in Signal Processing, Vol. 2.

[12] Chaubey, S., Patil, M. K. (2015): Correlation study and regression analysis of water quality assessment of Nagpur City, India. - International Journal of Scientific and Research Publications 5(11).

[13] Chen, F.-W., Liu, C.-W. (2012): Estimation of the spatial rainfall distribution using inverse distance weighting (IDW) in the middle of Taiwan. - Paddy and Water Environment 10(3): 209-222.

[14] Chiesa, S. (1983): Geology of the Dhamar-Rada' volcanic field, Yemen. - Arab Republic.

[15] Darwesh, N., Allam, M., Meng, Q., Halfdhallah, A., Ramzy S. M, N., El Kharrin, K., Al Malik, A. Belghyti, D. (2019): Using Piper trilinear diagrams and principal component analysis to determine variation in hydrochemical faces and understand the evolution of groundwater in Sidi Slimane Region, Morocco. Egyptian Journal of Aquatic Biology \& Fisheries Zoology Department, Faculty of Science, Ain Shams University, Cairo, Egypt 23(5): $17-30$.

[16] Davis, E., Ierapetritou, M. (2007): A kriging method for the solution of nonlinear programs with black-box functions. - AIChE Journal 53(8): 2001-2012.

[17] Elhag, M. (2016a): Inconsistencies of SEBS Model Output Based on the Model Inputs: Global Sensitivity Contemplations. - Journal of the Indian Society of Remote Sensing 44(3): 435-442.

[18] Elhag, M. (2016b): Evaluation of different soil salinity mapping using remote sensing techniques in arid ecosystems, Saudi Arabia. - Journal of Sensors Vol. 2016: 7596175.

[19] Elhag, M. (2016c). Detection of Temporal Changes of Eastern Coast of Saudi Arabia for Better Natural Resources Management. Indian Journal of Geo-Marine Sciences 45(1): 29-37.

[20] Elhag, M., Bahrawi, J. A. (2014). Potential rainwater harvesting improvement using advanced remote sensing applications. The Scientific World Journal 2014: p. 806959.

[21] Elhag, M., Bahrawi, J. A. (2016): Consideration of geo-statistical analysis in soil pollution assessment caused by leachate breakout in the municipality of Thermi, Greece. - Desalination and Water Treatment 57(57): 27879-27889. 
[22] Elhag, M., Bahrawi, J. A. (2017): Spatial assessment of landfill sites based on remote sensing and GIS techniques in Tagarades, Greece. Desalination and Water Treatment 91: 395-401.

[23] Elhag, M., Gitas, I., Othman, A., Bahrawi, J., Gikas, P. (2019): Assessment of Water Quality Parameters Using Temporal Remote Sensing Spectral Reflectance in Arid Environments, Saudi Arabia. - Water 11(3): 556.

[24] Geukens, F. (1966): Geology of the Arabian peninsula. - Translated from French by SD Bowers, Professional paper.

[25] Girard, M. (1975): Prélèvements d'échantillons en grotte et station de terrain sec en vue de l'analyse pollinique. - Bulletin de la Société préhistorique française 72(5): 158-160.

[26] Glass, N. (2010): The water crisis in Yemen: causes, consequences and solutions. Global Majority E-Journal 1(1): 17-30.

[27] Hartemann, P. (2000): L'eau et la sante. - Concours Medical 122(26): 1761-1761.

[28] Joshi, D. M., Bhandari, N. S., Kumar, A., Agrawal, N. (2009): Statistical analysis of physicochemical parameters of water of River Ganga in Haridwar district. - Rasayan Journal of Chemistry 2(3): 579-587.

[29] Khatoon, N., Khan, A. H., Rehman, M., Pathak, V. (2013): Correlation study for the assessment of water quality and its parameters of Ganga River, Kanpur, Uttar Pradesh, India. - IOSR Journal of Applied Chemistry 5(3): 80-90.

[30] Kot, B., Baranowski, R., Rybak, A. (2000): Analysis of mine waters using X-ray fluorescence spectrometry. - Polish journal of environmental studies 9(5): 429-432.

[31] Lesch, S., Suarez, D. (2009): A short note on calculating the adjusted SAR index. Transactions of the ASABE 52(2): 493-496.

[32] Overstreet, W., Kiilsgaard, T., Grolier, M., Schmidt, D., Domenico, J., Donato, M., Botinelly, T., Harms, T. (1985): Contributions to the geochemistry, economic geology, and geochronology of the Yemen Arab Republic. - US Geological Survey.

[33] Patil, P., Sawant, D., Deshmukh, R. (2012): Physico-chemical parameters for testing of water-A review. - International Journal of Environmental Sciences 3(3): 1194-1207.

[34] Piper, A. M. (1944): A graphic procedure in the geochemical interpretation of wateranalyses. - Eos, Transactions American Geophysical Union 25(6): 914-928.

[35] Rafiullah, M., Milind, J., Ustad, I. (2012): Physico chemical analysis of Triveni lake water of Amravati district in (MS) India. - Bioscience discovery 3(1): 64-66.

[36] Sabnavis, M., Patangay, N. S. (1998): Principles and applications of groundwater geophysics. - Association of Exploration Geophysicists.

[37] Sedgwick, P. (2012): Pearson's correlation coefficient. - BMJ 345: e4483.

[38] Singh, K. P., Malik, A., Mohan, D., Sinha, S. (2004): Multivariate statistical techniques for the evaluation of spatial and temporal variations in water quality of Gomti River (India)-a case study. - Water research 38(18): 3980-3992.

[39] Van den Brink, P. J., Ter Braak, C. J. F. (1999): Principal response curves: Analysis of time-dependent multivariate responses of biological community to stress. Environmental Toxicology and Chemistry 18(2): 138-148.

[40] Whiting, D. R., Guariguata, L., Weil, C., Shaw, J. (2011): IDF diabetes atlas: global estimates of the prevalence of diabetes for 2011 and 2030. - Diabetes research and clinical practice 94(3): 311-321.

[41] WHO (2003): Selenium in drinking-water: Background document for development of WHO guidelines for drinking-water quality. - World Health Organization.

[42] Yilmaz, N., Yardimci, C., Elhag, M., Dumitrache, C. (2018): Phytoplankton Composition and Water Quality of Kamil Abduş Lagoon (Tuzla Lake), Istanbul-Turkey. - Water 10(5): 603. 